\title{
A hybrid algorithm of BSC and QFD to determine the criteria affecting implementation of successful outsourcing
}

\author{
Mohammad Hemati ${ }^{*}$, Azim Zarei, Mosayeb Karami and Hamidreza Karkehabadi
}

Department of Industrial Engineering, Semnan Branch, Islamic Azad University, Semnan, Iran

\begin{tabular}{|c|c|}
\hline A R T I C L E I N F O & A B S T RAC T \\
\hline $\begin{array}{l}\text { Article history: } \\
\text { Received July } 25,2011 \\
\text { Received in Revised form } \\
\text { October, } 19,2011 \\
\text { Accepted } 29 \text { October } 2011 \\
\text { Available online } \\
5 \text { November } 2011 \\
\text { Keywords: } \\
\text { Outsourcing } \\
\text { BSC } \\
\text { Performance appraisal } \\
\text { QFD }\end{array}$ & $\begin{array}{l}\text { Successful organizations share some identical factors that pave the way for their success. } \\
\text { Among these factors, strategic management is the key to success for organizations to contribute } \\
\text { more to the competitive world market of today. In this respect, the pivotal role of outsourcing } \\
\text { cannot be denied. This research parallelizes the criteria affecting the outsourcing success as } \\
\text { presented in Elmuti model with the Balanced score card method in the Tose'e Ta'avon Bank. In } \\
\text { this research, questionnaires and interviews with experts helped determine the strategic goals at } \\
\text { four perspectives of balanced score card method (at Tose'e Ta'avon Bank) and the relative } \\
\text { weights were computed for each of balance score card (BSC) perspectives by using AHP } \\
\text { method. As the next step, the indexes were prioritized by applying the quality function } \\
\text { development(QFD) technique and considering strategic goals at four perspectives in section } \\
\text { "WHAT" and the outsourcing success criteria of Elmuti model in section "HOW". At the end of } \\
\text { algorithm, the results are compared with the Elmuti method. Based on the results, the hybrid } \\
\text { proposed technique seems to perform better than Elmuti. }\end{array}$ \\
\hline
\end{tabular}

(C) 2012 Growing Science Ltd. All rights reserved.

\section{Introduction}

In recent years, using the modern services management methods, including outsourcing, is known as one of the highly important processes. Outsourcing, therefore, sounds a crucial indicator in determining the criteria such as reliability, experience and the proper performance (Elmuti, 2003). Overall, executing the successful outsourcing strategy can help firms enhance organizational competition and financial operation, lower the costs, and improve the capacity, effectiveness as well as fitness of the activities (Kolawa, 2004). Investigations show that if outsourcing is conducted appropriately, it can be profitable for organizations. It can decrease the costs, and the need for investment at facility, equipment and human force. On the other hand, there are some evidences that an increase in outsourcing can decrease innovation and control the affairs (Elmuti, 2003).

Successful outsourcing is attained through proper implementation of strategic planning, execution and control. In this regard, strategic planning refers to comprehensive and suitable plans within the

\footnotetext{
* Corresponding author. Tel: +98-231-4458230

E-mail addresses: mo928hem@yahoo.com 
outsourcing phases. The balance score card (BSC) method can create a conceptual framework to convert different components into executive operations. There are four different components associated with any BSC implementation, which starts from learning, internal process, customer and financial. Quality function development (QFD), on the other hand, is another technique for assessing processes. The proposed model of this paper uses a hybrid method, which consists of BSC and QFD to determine the most important criteria affecting the successful implementation of outsourcing.

\section{Literature Review}

\subsection{Outsourcing}

Lacity and Hirschheim (1993) stated outsourcing as a form of contract activity, which has previously been performed at a firm, and now other firms perform it. As Rasheed (2000) defined, outsourcing as a contract agreement with an external firm for performing the activities which were previously performed at the firm, or performing the activities, which are fully new. The term outsourcing is usually applied when the firm breaks down the activities or attempts vertical analysis. The term was coined at the end of the 1980 and it was applied for minor contracts of management information systems. In the past, many contract services associated with informative segments or systems, but in recent years, many other functions in various sections including departmental services, human forces activities, remote relations, customer services, logistic and even security have been outsourced. Successful organizations share the same factors of success and they have a correct understanding of their own principal activities. They have proper and competent planning and researches, and most importantly, they have extended expectations, intents and objectives (Elmuti, 2003). Another important element which is important in successful outsourcing is the proper external organization supplier. It is necessary to select the suitable supplier based on criteria like the proper performance, experiment, and reliability (Elmuti, 2003). A higher access to new markets, more competitive advantages, trading with greater suppliers, as well as a more advanced technology and skill are some other advantages of successful outsourcing (Thomas, 2004).

In a study on outsourcing, Ndubisi (2011) examined the cultural differences in Malaysia and factors including commitment and trust in outsourcing. The results showed that cases including commitment and trust at Indian and Chinese samples had a significant difference. In another study, Ullah Khan et al. (2011) sought to identify and analyze the important factors for successful outsourcing in Asia, North America and Europe. The results indicated saving the costs as the most important factor, while factors including the skillful human force, proper substructures and services as well as product were reported as the next priorities, respectively. In another study, Koskela and Stenbacka (2009) attempted to examine the effect of outsourcing on the amount of unemployment and distribution of wages in an effort to increase the outsourcing and direct external investment.

In Japan, a study was conducted on 396 outsourcing projects by prominent firms like Toshiba, Hitachi, Fojitso and Mitsobishi (Bush et al., 2008). These researchers presented an analytic model for anticipating successful outsourcing at various projects. In another study in Japan, Shi et al. (2011) sought to elicit experts' perceived risk of software offshore outsourcing incorporating individual heterogeneity. They interviewed 20 people and observed the individuals' heterogeneity and requirement volatility as the most important factor in making software outsourcing decisions in Japan. Additionally, they made an attempt to answer the question whether country preferences are in software outsourcing of Japan or whether different kinds of outsourcing software influence differently on risk perception. It was found that skillful managers have quiet neutral attitude toward kinds of software and vendor country aspects. Shi et al. (2011) suggested an incorporated approach of linear model (LMM) to make individual's heterogeneity explicit by the use of conjoint analysis experimental framework. Karimi et al. (2011) investigated the reasons why transaction cost theory (TCT) for studing information technology outsourcing created mixed results. For this purpose, they investigated 25 related studies between 1995 and 2011 from 19 different journals. As it was indicated 
in their analysis of empirical ITO models, not all transaction cost theories were applied as a conceptualization in TCT and not all TCT relations were taken into account. Tjader et al. (2010) investigated the best policy for outsourcing business activities. They used analytical network process (ANP), a multi criteria decision making method and ANP super decision software for developing the decision model. The model provides both short term and long term perspectives of the corresponding outsourcing issue to all groups. They examined four policy options in decision makers, stockholders and influence groups' views with respect to 50 economic, political, technological and other factors. They proposed an appropriate framework for investigating legal options with regarding offshore outsourcing and observed that providing displaced workers' assistance program is the best approach in US government.

In a study in Taiwan, James et al. (2011) employed an incorporated model (new hybrid multiple criteria decision making (MCDM) model) for appropriate selection of outsourcing providers using the Taiwan aviation data. They implemented ANP for weighting and DEMATEL was employed for selecting outsourcing providers. They reported that the most important criteria appeared to be information security (15.9\%), followed by on-time rates $(14.9 \%)$, lack of management control $(14.4 \%)$, and customer satisfaction (12.2\%). These results do not necessarily mean that little attention should be paid to other factors like compatibility. Moon (2010) developed a model for partial outsourcing under a market uncertainty to provide a firm with an outsourcing strategy and making a corresponding support decision system. Based on this model, management implications were provided on how outsourcing timing strategy should vary when outsourcing environments such as market uncertainty change. As Moon (2010) reports, when market becomes more stable, higher marginal profits are expected from outsourcing. When a firm outsources more shares and its effort at the preparation stage is more efficient, it can outsource earlier. Furthermore, Moon (2010) conducted a comparative study of a real option approach and a net present value method to conclude that NPV underestimates the firm's values and proposes the earlier partial outsourcing.

Hotels are appropriate places for investigation of effective factors on outsourcing activities by extensive range of services in this industry. Lamminmaki (2011) investigated the factors motivating hotel outsourcing using interviews and questionnaires. In this research, 20 related factors to transaction cost economics and outsourcing incentives were considered. Out of these factors, 10 were categorized as incentive outsourcing factors while the others were classified as leading concerns of outsourcing activities. Lee and Choi (2011) studied the effects of initial and ongoing trust in IT outsourcing from outsourcers and service providers. Data were collected from 148 service providers and receivers in a 6-month period and were analyzed by PLS Graph version3 software. The results indicated that ongoing trust and distrust between the provider and receiver was necessary in profit earning and that output was influenced by participants' perceptions at the first stage of outsourcing process. They also proved that knowledge sharing experience mediated the effect of primary trust and distrust, and in constant, trust and distrust among groups in different ways. They concluded that changes in service providers' primary perceptions were apparently more positive and visible than those receiving services, however, both primary perceptions were cognitively compatible.

\subsection{Balanced score card method}

Performance evaluation and performance management are the result of strategic and operational plans of the organization. Although, compilation of strategic and operational plans is an intricate and complicated process, their successful execution is more difficult (Makhijani \& Creelman, 2008).Since one of the principle objectives of this article is to prioritize the outsourcing criteria with balanced scorecard (BSC) process, performance appraisal and BSC are briefly examined. 


\subsection{Definitions of the performance appraisal and BSC}

The performance appraisal is defined as the process of quantifying the operation effectiveness and efficiency (Neely et al., 1996). Optimal allocation of sources to an organization, foundation or industry involves measuring the performance of their units. Bank discipline has a very heavy responsibility at market-based economics. It offers services, without which the country bank discipline stops. The capital present in banks is the principle source for buying the products and services, and their offered facilities is a source for providing credit for all the economic units like families, occupations, firms and the government. Banks hold the certain acreage and provide the customers with a set of investment, technological, research and service units, participation in economics, teaching, informing, councilors and commerce. One of the important reasons why organizations use the applied plans is acquiring and long-term conserving the customer and giving value for him/her called customer relationship management (CRM) (Huang, 2009). The performance measurement can be defined as a system by which the organization controls and assesses its routine performance; that is, whether the organization achieves its objectives (Wu et al., 2009). There are two traditional principles and modern views for performance appraisal discussions. The traditional view, with an order style targets the performance reminding and judging as well as the assessed controlling. The modern view targets teaching, growing and extending the assessed capacities, improving and refining the individuals and the organization and its performance, presenting the counseling services and public beneficiaries participation, creating incentive and responsibility for improving the quality and refining the activities and operation. Its basis is to identify the weakness and strength as well as elevating the quality of the organization. Among the known performance measurement frames, which are broadly used is EFQM. This frame includes two separate classes, which are generally divided into "Enablers" and "results". Enablers include leadership, policies and strategies, partnerships and resources, people and processes. Results include people results, customer results, society results and key performance results. The other method is BSC presented in 1996 by David Norton in Norton Nolan institute and by Robert Kaplan, a Harvard university professor. This method measures the organization performance from four perspectives: financial, learning and growth, customers, internal process and relating to four types of performance: accounting, financial, marketing, value chain and human resources (Wu et al., 2009). BSC includes four criteria classes: financial, learning and growth, customer and internal process, which constitute its four perspectives. Balance term in BSC means:

- Creating the balance between financial and non-financial criteria,

- Creating the balance between external and internal criteria.

Today, BSC is recognized as a strategic management system and also a learning system which is based on the comprehensive objectives of a corporation and considers creating value in loge-term. BSC principle core is formed by perspective and strategy. These two are, in fact, a basis for forming four BSC perspectives and the financial results are attained through other three BSC components. BSC innovators at their second article in 1993 introduced BSC as not only a measuring system but also a management system and emphasized the organization strategy, commission and respective role in it (Rigby, 2001). Some of the studies conducted by using BSC are briefly presented here.

Davis and Albright (2004) examined the effect of dismounting BSC on improving the financial performance of a bank and acquired this result that by executing the strategic plan, the financial performance is significantly improved. Wu et al. (2009) compared the results of dismounting BSC in three banks and attempted to prioritize them by using fuzzy decision-making methods, and concluded that the order of setting four dimensions for assessing the banks performance is as customer (0.4101), financial (0.3271), internal process (0.1314) and growth and learning (0.1314). Wu et al. (2011) attempted to assess the performance some teaching centers by using BSC. They conducted their research at three universities in Taiwan and attempted to examine the causality relationship among indexes by using DEMATEL technique. 


\section{Methodology}

\subsection{Executive research procedures}

In this article, for accessing the hybrid outsourcing algorithm and BSC, six steps are followed:

1. Determine the outsourcing indexes based on Elmuti method and statistical techniques,

2. Determine the strategic objectives based on four BSC perspectives,

3. Determining the relative weights of BSC perspectives,

4. Use Quality Function Development technique:

By applying the Quality Function Development (QFD) technique, firms can allocate their resources in accordance with their customers' desires and coordinate the various organization sections as well as their experts' skills (Almannai et al., 2008).

5. Determine the priorities of the outsourcing indexes with the strategic attitude,

6. Compare the results and analyze the data. The procedures are summarized in Fig. 1.

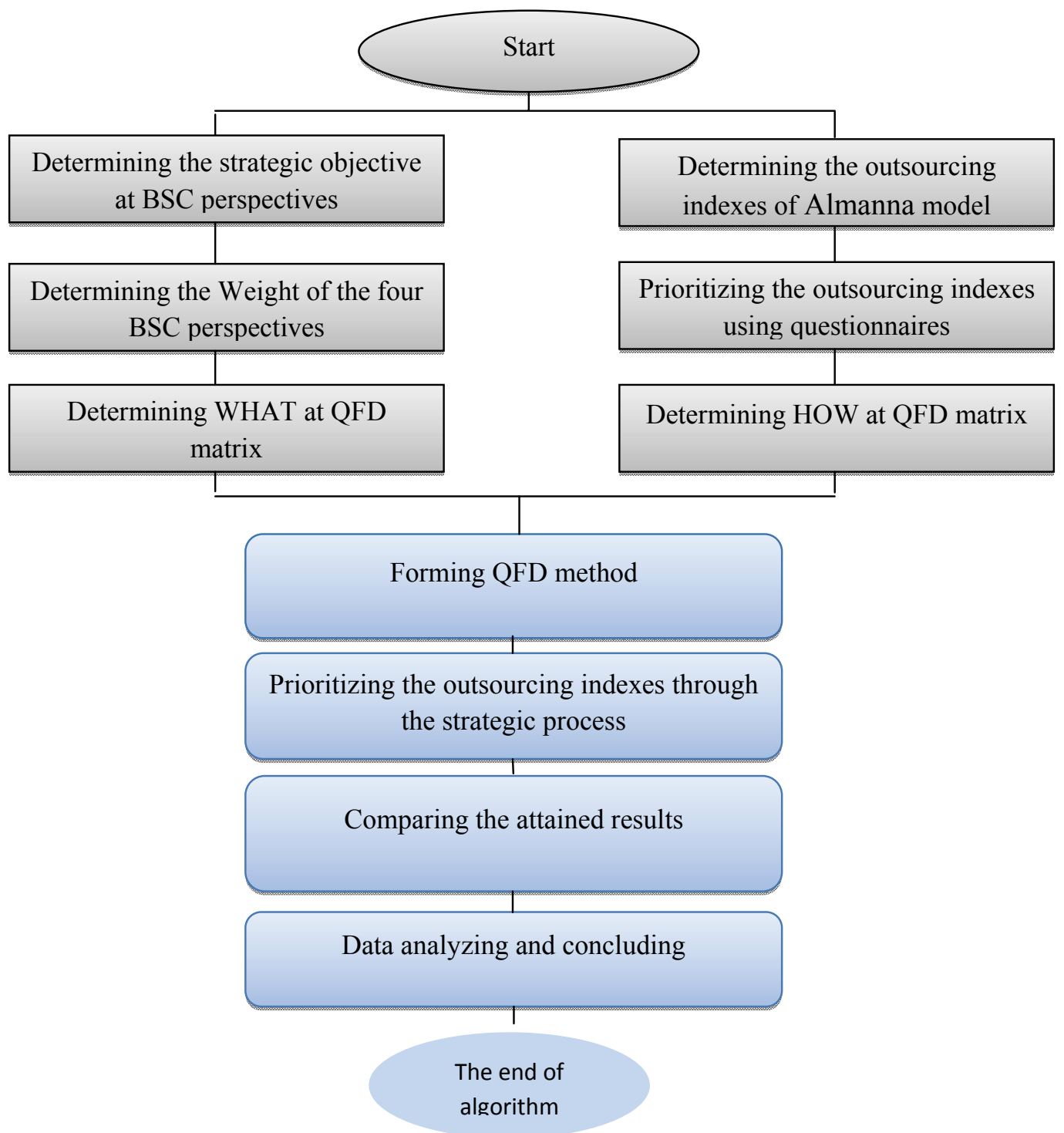

Fig. 1. The execution of the proposed algorithm 


\subsection{Introducing Tose'e Ta'avon Bank}

In execution of subsection of amendment of the National Budget Law enacted on 1990, and to provide facilities for the goal of mentioned above subsection and in execution of credit facilities indicated in amendment of article of the Cooperative Sector Law of the IRIN Economy enacted on 1992 , the Cooperative Fund established in 1990. The Fund and its domain of operation provides the financial resources by gathering proceeds from the resources of paying back of the government loans to centers in charge of productive and constructive services expansion and their relevant cooperatives or candidates members who by organizing such institutions with business plans for unemployed people occupation taking advantage of the mentioned loans.

Tose'e Ta'avon Bank has 346 branches around Iran. These branches have a total of 2,479 personnel, including the accounting staff and guardianship workers. The managers, experts and branch directors constitute the research population as the organization elite personnel. A total of 32 participants from the given branch directors, experts and managers were selected.

With regard to the high amount of contracts that Tose'e Ta'avon Bank has had in recent years, this bank has been selected for the case study of this article.

\section{Data analysis}

Stage 1: Determination of the outsourcing indexes

After developing the questionnaire, it was tested through a pilot study, which involves administering the instrument to 20 target participants selected from the sample. The reliability of the questionnaire is measured by using Cronbach`s Alpha test. The attained Alpha was $89.72 \%$, which is well above the minimum acceptable level of $70 \%$, suggesting that the reliability of the instrument was high. For specifying the appropriate statistical test, tests of normality were executed. For this purpose, Kolmogorov-Smirnov T test (KS test) was run and because, in all tests, the $p$ value was more than .05 , it was concluded that the observation distribution followed a normal distribution. In addition, in order to prioritize each value, Friedman and one-way ANOVA tests were run. The results showed that $p$ value was less than 5\%, it was concluded that the effect of 9 indexes on the customer services management was significant. In order to prioritize factors, which affects the outsourcing, we have used the mean rate. Table 1 presents the results by using of mean scores.

\section{Table 1}

Prioritizing the factors affecting outsourcing

\begin{tabular}{clcc}
\hline Priority & Factors in reference to their priority & Mean rate & Percentage \\
\hline 1 & Emphasizing on long-and short-term interest & 5.51 & 12.2 \\
2 & The suitable criteria for measuring the performance & 5.44 & 12.1 \\
3 & Holding the cooperation spirit among workers & 5.15 & 11.4 \\
4 & Paying the suitable wage to workers & 5.12 & 11.4 \\
5 & Proper planning among the various outsourcing phases & 5.07 & 11.3 \\
6 & Effective organization communication & 4.79 & 10.6 \\
7 & Receiving the proper feedback from organization performance & 4.77 & 10.6 \\
8 & Supporting the senior manager & 4.70 & 10.4 \\
9 & Proper skill at performing the talks & 4.44 & 9.9 \\
\hline
\end{tabular}

Stage 2 The strategic objectives at four BSC perspectives

At this stage, the BSC team collected the necessary information from the branch directors, experts and managers at the strategic positions of the organization. After collecting the responses, BSC team assigned the following strategic objectives used at the next stages. In Fig. 2 the strategic objectives at BSC perspectives has been represented. 


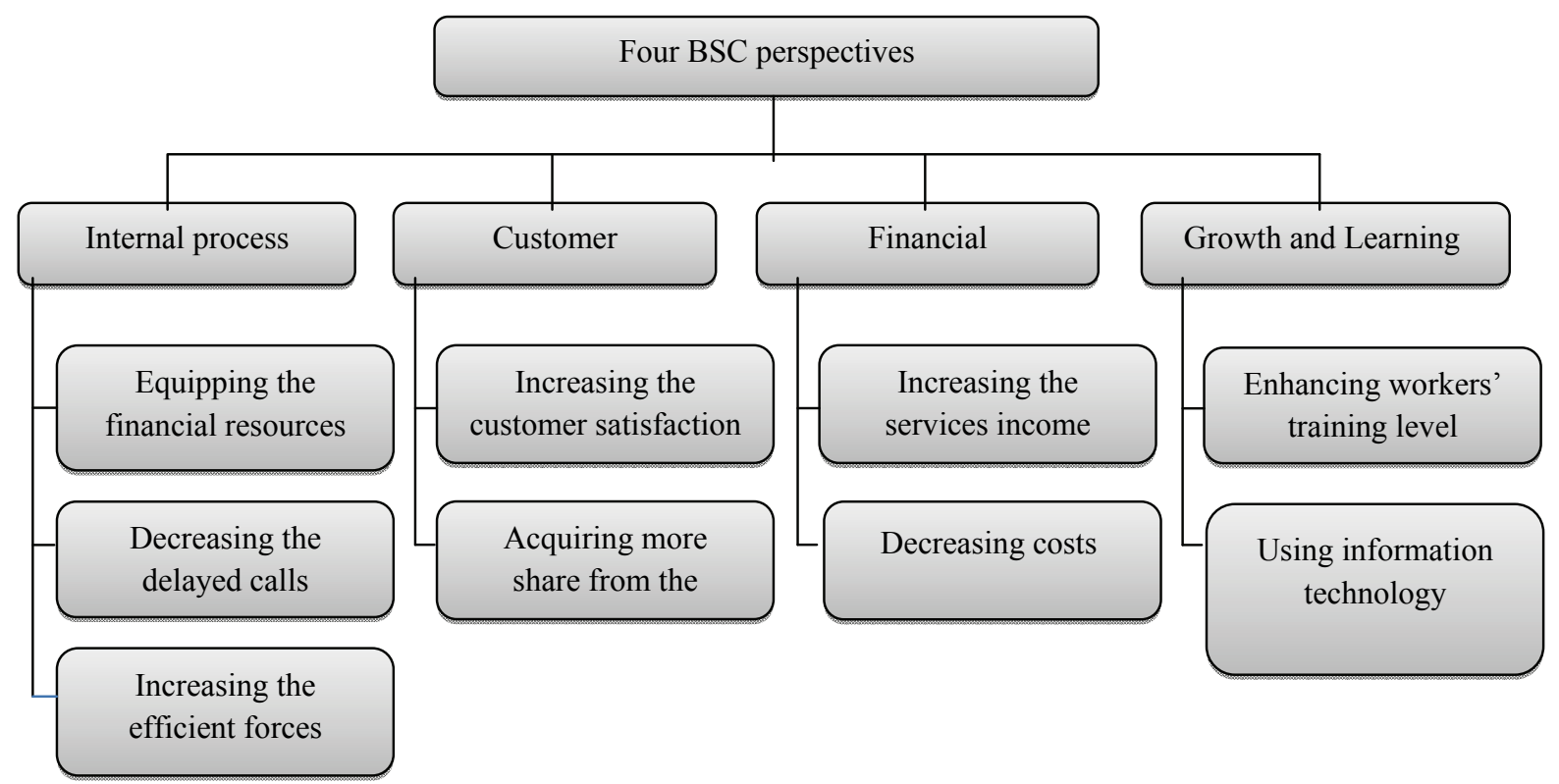

Fig. 2. Strategic objectives at BSC perspectives

Stage 3: The relative BSC weights

According to the elites' views the relative BSC weights were determined. Table 2 presents the results of the pair-wise comparisons matrix. It shows the elites' point of view toward the four BSC perspectives. The inconsistence degree is about 0.05 that is less than 0.1 and is acceptable. Table 2, shows the weights produced from the pair-wise comparisons matrix the elites' point of view toward the four BSC factors. Since, the Tose'e Ta'avon Bank is a government bank, the internal process aspect, according to the present mission of government and non-government organizations, enjoys a higher priority.

Table 2

Weights attained from the pair-wise comparisons matrix

\begin{tabular}{lc}
\hline Macro- objectives & Weight \\
\hline Financial aspect & 0.121 \\
Internal process aspect & 0.382 \\
Customer-based aspect & 0.251 \\
Growth and learning aspect & 0.246 \\
\hline
\end{tabular}

Stage 4: QFD implementation

At this stage, the strategic objectives (objectives presented in BSC perspectives) were inserted in part WHAT and the success models of Elmuti model were inserted in part WHO at QFD. The relationships among each of the strategic objectives and Elmuti model were assigned points following the scoring method presented by Lee et al. (2000). The method involves allocating score 9 for the highest relationship, score 3 for an average relationship, score 1 for a weak relationship, and zero for no relationship.

$$
\mathrm{A}_{\mathrm{i}}=((\mathrm{F} 1 \mathrm{i}+\mathrm{F} 2 \mathrm{i}) / 2) \times \mathrm{W}_{1}+((\mathrm{C} 1 \mathrm{i}+\mathrm{C} 2 \mathrm{i}) / 2) \times \mathrm{W}_{2}+((\mathrm{P} 1 \mathrm{i}+\mathrm{P} 2 \mathrm{i}) / 2) \times \mathrm{W}_{3}+((\mathrm{L} 1 \mathrm{i}+\mathrm{L} 2 \mathrm{i}) / 2) \times \mathrm{W}_{4}
$$

where

$A_{i}=$ The index score affecting on outsourcing by accounting for BSC objectives

$F_{i}=$ Financial perspective objectives 
$C_{i}=$ Customer perspective objectives

$P_{i}=$ Internal process perspective objectives

$L_{i}=$ Growth and Learning perspective objectives

$W_{i}=$ Weight of each of BSC perspectives in Table 2

Table 3

Score of each outsourcing index, by accounting for the weights of the four BSC perspectives

\begin{tabular}{|c|c|c|c|c|c|c|c|c|c|c|c|}
\hline $\mathrm{BSC}$ & & A1 & $\mathrm{A} 2$ & A3 & A4 & A5 & A6 & A7 & A8 & A9 & Score \\
\hline \multirow{4}{*}{ Financial } & $\begin{array}{l}\text { Increasing the income } \\
\text { produced from services }\end{array}$ & 9 & 3 & 1 & 0 & 9 & 3 & 3 & 9 & 1 & 37 \\
\hline & Decreasing the costs & 3 & 1 & 1 & 1 & 0 & 0 & 9 & 1 & 3 & 16 \\
\hline & $\begin{array}{l}\text { Index score by accounting } \\
\text { for the weight of each } \\
\text { perspective }\end{array}$ & 0.73 & 0.24 & 0.12 & 0.06 & 0.54 & 0.18 & 0.73 & 0.61 & 0.24 & 3.21 \\
\hline & $\begin{array}{l}\text { Increasing customer } \\
\text { satisfaction }\end{array}$ & 9 & 9 & 9 & 9 & 3 & 9 & 3 & 9 & 1 & 60 \\
\hline \multirow[b]{2}{*}{ Customer } & $\begin{array}{l}\text { Acquiring more share from } \\
\text { the market }\end{array}$ & 3 & 3 & 9 & 1 & 3 & 3 & 9 & 3 & 1 & 34 \\
\hline & $\begin{array}{l}\text { Index score by accounting } \\
\text { for the weight of each } \\
\text { perspective }\end{array}$ & 1.48 & 1.48 & 2.21 & 1.23 & 0.74 & 1.48 & 1.48 & 1.48 & 0.25 & 11.6 \\
\hline \multirow{3}{*}{ Process } & $\begin{array}{l}\text { Equipping the financial } \\
\text { resources }\end{array}$ & 9 & 3 & 9 & 3 & 9 & 3 & 9 & 3 & 3 & 48 \\
\hline & Decreasing the delayed calls & 9 & 9 & 3 & 1 & 1 & 3 & 9 & 0 & 1 & 35 \\
\hline & $\begin{array}{l}\text { Index score by accounting } \\
\text { for the weight of each } \\
\text { perspective }\end{array}$ & 3.44 & 2.29 & 2.29 & 0.76 & 1.91 & 1.15 & 3.44 & 0.57 & 0.76 & 15.9 \\
\hline \multirow{3}{*}{$\begin{array}{l}\text { Growth } \\
\text { and } \\
\text { Learning }\end{array}$} & $\begin{array}{l}\text { Enhancing the workers' } \\
\text { training level }\end{array}$ & 9 & 1 & 3 & 3 & 0 & 1 & 1 & 9 & 0 & 27 \\
\hline & $\begin{array}{l}\text { Using modern technology } \\
\text { and IT information } \\
\text { technology }\end{array}$ & 9 & 0 & 9 & 0 & 3 & 3 & 3 & 9 & 1 & 36 \\
\hline & $\begin{array}{l}\text { Index score by accounting } \\
\text { for the weight of each } \\
\text { perspective }\end{array}$ & 2.26 & 0.13 & 1.51 & 0.38 & 0.38 & 0.5 & 0.5 & 2.26 & 0.13 & 7.91 \\
\hline \multicolumn{2}{|c|}{ Score sum of each index } & 60 & 29 & 44 & 18 & 28 & 25 & 46 & 43 & 11 & \\
\hline \multicolumn{2}{|c|}{$\begin{array}{l}\text { Score of each index by accounting for the } \\
\text { weight of each BSC perspective }\end{array}$} & 7.9 & 4.14 & 6.13 & 2.43 & 3.57 & 3.31 & 6.14 & 4.91 & 1.38 & 38.5 \\
\hline \multicolumn{2}{|c|}{$\begin{array}{l}\text { Percentage of each index by accounting } \\
\text { for the weight of each BSC perspective }\end{array}$} & 21 & 11 & 16 & 6 & 9 & 9 & 16 & 13 & 4 & 1 \\
\hline
\end{tabular}

A1: emphasizing on the long- and short-term organization interest

A2: holding the cooperation spirit among workers

A3: receiving the proper feedback from the organization performance

A4: paying the proper wages to workers

A5: the proper planning of the outsourcing phases

A6: the proper criteria for measuring the organization performance

A7: the proper organization communication

A8: supporting the senior managers of organization from the outsourcing activities

A9: the proper skill at performing the outsourcing discussions

Stage 5: The outsourcing indexes with a strategic view

At this stage, after QFD was developed, it was administered in the form of a questionnaire, to the organization elites and the results are summarized in Table. According to the findings, the following points can be concluded that an outsourcing positively influence customer service management. The important factors include emphasizing on the long and short term organization interests, the proper criteria for measuring the performance, holding the cooperation spirit among workers, fair payments 
to workers, proper planning in various outsourcing phases, effective organization communication, having proper feedback from the organization performance, supporting the senior manager, and finally the proper skill at doing the discussions. In terms of priority of the factors the factors include emphasizing on the long and short term organization interests, receiving proper feedback from the organization performance, holding cooperation spirit among workers, supporting senior managers, proper criteria for measuring the performance, effective organization communication, paying the proper wage to the workers, and proper skill for doing the talks.

\section{Table 4}

Prioritizing the factors affecting the outsourcing with BSC process

\begin{tabular}{clc}
\hline Priority & Identified factors with respect to their priority & Percentage \\
\hline 1 & Emphasizing on long-and short-term interest & 17.2 \\
2 & The suitable criteria for measuring the performance & 10.1 \\
3 & Holding the cooperation spirit among workers & 14.5 \\
4 & Paying the suitable wage to workers & 7.21 \\
5 & Proper planning among the various outsourcing phases & 10.3 \\
6 & Effective organization communication & 8.96 \\
7 & Receiving the proper feedback from organization performance & 15.1 \\
8 & Supporting the senior manager & 12.8 \\
9 & Proper skill at performing the talks & 4.01 \\
\hline
\end{tabular}

Table 5 presents the results of the comparison of the two BSC and statistical methods.

\section{Table 5}

Comparison of the results obtained from the two BSC and statistical methods

\begin{tabular}{llcc}
\hline Priority & Identified factors with respect to their priority & $\begin{array}{c}\text { Mean percent with the } \\
\text { statistical methods }\end{array}$ & $\begin{array}{c}\text { Mean percent with } \\
\text { BSC method }\end{array}$ \\
\hline 1 & Emphasizing on long-and short-term interest & 12.2 & 17.2 \\
2 & The suitable criteria for measuring the performance & 12.1 & 10.1 \\
3 & Holding the cooperation spirit among workers & 11.4 & 14.5 \\
4 & Paying the suitable wage to workers & 11.4 & 7.21 \\
5 & Proper planning among the various outsourcing phases & 11.3 & 10.3 \\
6 & Effective organization communication & 10.6 & 8.96 \\
7 & Receiving the proper feedback from organization performance & 10.6 & 15.1 \\
8 & Supporting the senior manager & 9.9 & 12.8 \\
9 & Proper skill at performing the talks & 4.01 \\
\hline
\end{tabular}

\section{Conclusion}

In this paper, we have presented a new method, which is a hybrid of balanced score card and quality function deployment. The hybrid method has been used to study the important factors influencing successful implementation of outsourcing in banking industry. The proposed study of this paper has been implemented for real-world case study of an Iranian bank industry and the results are compared with another existing method. The preliminary results indicate that the proposed model of this paper performs better than the alternative one. The results indicated that different factors play important roles for the successful implementation of outsourcing and we hope the results of this survey could help banking industry.

\section{References}

Almannai, B., Greenough, R.M., \& Kay, J.M. (2008). A decision support tool based on QFD and FMEA for the selection of manufacturing automation technologies. Robotics and ComputerIntegrated Manufacturing, 4(24), 501-507.

Bush, A.A., Taiwana, A., \& Tsuji, H. (2008). An empirical investigation of the drivers of software outsourcing decisions in Japanese organizations. Information and Software Technology, 50(6), 499-510. 
Davis, S., \& Albright, T. (2004). An investigation of the effect of Balanced Scorecard implementation on financial performance. Management Accounting Research, 15, 135-153.

Elmuti, D. (2003). The perceived impact of outsourcing on organizational performance. American Journal of Business, 18(2), 33-41.

Huang, H.C. (2009). Designing a knowledge-based system for strategic planning: A balanced scorecard perspective. Expert Systems with Applications, 36(1), 209-218.

Karimi Alaghehband, F., Rivard, S., Wu, S., \& Goyette, S. (2011). An assessment of the use of transaction cost theory in information technology outsourcing. The Journal of Strategic Information Systems, 20, 125-138.

Koskela, E., \& Stenbacka, R. (2009). Equilibrium unemployment with outsourcing under labor market imperfections. Labor Economics, 16, 284-290.

Kolawa A. (2004). Outsourcing is not the enemy. WallStreet Journal (Eastern Edition), February 24. pB-2.

Lacity, M., \& Hirschheim, R. (1993). The Information Systems Analysis: Myths, Metaphors, and Realities. New York: John Willey and Sons.

Lamminmaki, D. (2011). An examination of factors motivating hotel outsourcing. International Journal of Hospitality Management, 30, 963- 973.

Lee, J.N., \& Choi, B. (2011). Effects of initial and ongoing trust in IT outsourcing: A bilateral perspective. Information \& Management, 48, 96-105.

Lee, S.F., Lo, K.K., Leung, R.F., \& Sai, K.A. (2000). Strategy formulation framework for vocational education: Integrating SWOT Analysis, Balanced Scorecard, QFD Methodology and MBNQA educational criteria. Managerial Auditing Journal, 15(8), 407-423.

Wu, H.Y., Tzeng, G.H., \& Chen, Y.H. (2009). A fuzzy MCDM approach for evaluating banking performance based on Balanced Scorecard. Expert Systems with Applications, 36(6), 10135-10147

James, J. H., Liou, H. S., Wang, C.C, \& Hsu, S. L. ( 2011). A hybrid model for selection of an outsourcing provider. Applied Mathematical Modelling, 35, 5121-5133.

Makhijani N., Creelman, J. (2008). How leading organizations successfully implement corporate strategy with the balanced scorecard. The OTI Thought Leadership Series, 1, 1-16.

Moon, Y. (2010). Efforts and efficiency in partial outsourcing and investment timing strategy under market uncertainty. Computers \& Industrial Engineering, 59, 24-33.

Neely, A., Mills, J., Gregory, M., Richards, H., Platts, K., \& Bourne, M. (1996). Getting the Measure of Your Business. Works Management, University of Cambridge.

Ndubisi, N.O. (2011), Mindfulness, reliability, pre-emptive conflict handling, customer orientation and outcomes in Malaysia's healthcare sector. Journal of Business Research, 40, 109-117.

Rigby, D. K. (2001). Management Tools, Global Results. Annual Survey of Senior Executives: Survey, Bain \& Company, Boston MA, available at: www.bain.com.

Shi, X., Tsuji, H., \& Zhang, S. (2011). Eliciting experts' perceived risk of software offshore outsourcing incorporating individual heterogeneity. Expert Systems with Applications, 38: 22832291.

UllahKhan, S., Niazi, M., \& Rashid, A. (2011). Factors influencing clients in the selection of offshore software outsourcing vendors: An exploratory study using a systematic literature review. Journal of systems and software, 84(4), 686-699.

Wu, H.Y., Lin, Y.K., \& Chang, C.H. (2011). Performance evaluation of extension education centers in universities based on the balanced scorecard. Evaluation Program Planning, 34(1), 37-50.

Tangen, S. (2004). Professional practice performance Measurement: from philosophy to practice. International Journal of Productivity and Performance Management, 53(8), 26-37.

Thomas, P. (2004). Small business - case study: the time to diversify is before it's too late. WallStreet Journal, (EasternEdition), March 2, p. B4.

Tjader, Y.C., Shang, J.S., \& Vargas, L.G. (2010). Offshore outsourcing decision making: A policymaker's perspective. European Journal of Operational Research, 207(1), 434-444. 